\title{
THE INFLUENCE OF A DIET RICH IN WHEAT FIBRE ON THE HUMAN FAECAL FLORA
}

\author{
B. S. Drasar*, D. J. A. Jenkins† and J. H. Cummings † \\ * Bacterial Metabolism Research Laboratory, Public Health Laboratory Service, Colindale \\ Avenue, London NW9 5DX, and † MRC Gastroenterology Unit, Central Middlesex \\ Hospital, London NWIO
}

MANY of the diseases peculiar to western civilisation have been ascribed to the removal from the diet of the major part of the fibre of the wheat grain. It has been suggested that this part of the wheat grain, known as bran, is of specific value in the prevention of various diseases including large bowel cancer (Burkitt, 1971). The prophylactic influence of bran is ascribed to its effects on intestinal transit, faecal bulk and the faecal flora. The effect of bran on intestinal transit and faecal bulk has been previously documented (Cowgill and Anderson, 1932; Harvey, Pomare and Heaton, 1973). In this paper we describe the effect of bran on the faecal flora.

\section{MATERIALS AND METHODS}

Plan of Study. Four healthy male medical students (nos. 1-4) aged 22-25 took part in the study. The protocol was fully explained to each subject and had been approved by the ethical committee of the Central Middlesex Hospital. For 6 weeks the subjects ate a carefully prepared metabolic diet whilst living in a hostel in the hospital grounds and carrying out their normal occupations.

The basic diet was a $2902 \mathrm{~K}$ cal. low-fibre diet of normal "western " composition comprising $351 \mathrm{~g}$ of carbohydrate, $122 \mathrm{~g}$ of fat and $88 \mathrm{~g}$ of protein, and it contained $3.6 \mathrm{~g}$ of crude fibre. This was fed for 3 weeks; for the other 3-week period the fibre content of the diet was increased (high fibre diet) by substituting an equal weight of wholemeal bread for the white bread $(120 \mathrm{~g})$, All-bran for cornflakes ( $25 \mathrm{~g})$, bran biscuits for Nice biscuits $(52 \mathrm{~g})$, and by adding $30 \mathrm{~g}$ of bran (Allison's Bran +). The high-fibre diet supplied $2775 \mathrm{~K}$ cal. as $339 \mathrm{~g}$ of carbohydrate, $115 \mathrm{~g}$ of fat and $97 \mathrm{~g}$ of protein, and it contained $11.7 \mathrm{~g}$ of crude fibre. Apart from the substitutions, the two diets were identical. Data were not available for the dietaryfibre (as opposed to crude-fibre) content of all the items, but this information was obtained for the four items changed in the two diets by the method of Southgate (1969). From this it was calculated that the high-fibre diet contained an additional $36 \mathrm{~g}$ of dietary fibre. Subjects nos. 1-2 took the low-fibre diet first and subjects nos. 3-4 the high-fibre diet first. Further details of the diets are given by Jenkins, Hill and Cummings (1975).

Throughout the 6-week period and for 1 further week the subjects collected their faeces. Each stool was collected separately into a plastic bag fixed over a toilet.

Mean transit time (MTT) was measured during the third week of each diet period by giving a single dose of 25 opaque pellets with breakfast and determining their presence in the collected stools radiographically.

Preservation of specimens. From a freshly passed stool, $0.5 \mathrm{~g}$ of faeces was mixed with $4.5 \mathrm{ml}$ of glycerol broth $10 \%(\mathrm{v} / \mathrm{v})$ in a 10-ml screw-capped bottle. The suspension was

Received 3 Dec. 1975; revised version accepted 17 Feb. 1976.

$\ddagger$ Present address: Dunn Nutrition Unit, Milton Road, Cambridge.

J. MED. MICROBIOL.-VOL. 9 (1976) 
placed in a container of solid carbon dioxide and was stored at $-80^{\circ} \mathrm{C}$. This procedure ensured that losses of bacteria are minimised (Crowther, 1971).

Culture of specimens. Serial dilutions of the specimens were prepared and plates of media for the isolation of anaerobic organisms were seeded within an anaerobic chamber. A flexible polyvinyl chamber filled with a mixture of $10 \%$ hydrogen in nitrogen was used (Aranki et al., 1969; Drasar, 1974).

To maintain the media in a reduced state, uninoculated plates were stored for 3 days in the anaerobic cabinet before use. The diluent was heated to $100^{\circ} \mathrm{C}$ before being introduced into the cabinet where it was dispensed and allowed to cool in the anaerobic environment. Plates seeded within the cabinet were packed into anaerobic jars and removed from the cabinet via the airlock. All anaerobic jars were evacuated and filled with a gas mixture containing $\mathrm{CO}_{2} 30 \%$ and $\mathrm{H}_{2} 70 \%$. The atmosphere of the anaerobic jars was replaced twice. Cold "D" catalyst (Engelhard Industries, Cinderford, Gloucestershire) was used in the anaerobic jars.

Ten-fold dilutions of the specimen were prepared in Brain-Heart Infusion Broth (Oxoid) with the addition of cysteine hydrochloride $0.05 \%(\mathrm{w} / \mathrm{v})$ and sodium formaldehydesulphoxalate $0.03 \%(w / v)$. Samples $(0.1 \mathrm{ml})$ of appropriate dilutions were spread on the surface of the plates of the various selective and non-selective media used in previous studies (Drasar, 1967). In addition to these media, Brain-Heart Infusion Agar (Oxoid) containing (w/v) Yeast Extract (Oxoid) $1 \%$, cysteine hydrochloride $0.05 \%$ and sodium formaldehydesulphoxalate $0.03 \%$, enriched with $10 \%$ defibrinated horse blood was used for the isolation of non-sporing anaerobic bacteria and this medium supplemented with $10 \%$ bile (Oxoid) and kanamycin sulphate $1000 \mu \mathrm{g}$ per $\mathrm{ml}$ was used to ensure the selection of Bacteroides fragilis.

After incubation, the colonies growing on the various media were counted. Ten strains of non-sporing anaerobic bacteria and 10 strains of clostridia were sampled from each specimen. The non-sporing anaerobes were further identified as described previously (Peach et al., 1974). The volatile fatty acid end-products of glucose metabolism were detected with a Perkin-Elmer F.40 Automatic head-space analyser (Drasar et al., 1976).

The ability of the clostridia to dehydrogenate the steroid nucleus was tested with the improved method of Goddard et al. (1975).

Faecal glucoronidase assay. The amount of $\beta$-glucuronidase in faecal specimens was assayed as described by Reddy and Wynder (1973).

\section{RESULTS}

The addition of fibre to the diet produced no demonstrable change in the relative numbers of the groups of bacteria counted in the faeces; the results obtained during the final week of each of the test diets are compared in the table. However, the output of faeces was increased on the high-fibre diet from $74 \cdot 5 \pm 14 \cdot 3 \mathrm{~g}$ per day to $223 \pm 33 \cdot 2 \mathrm{~g}$ per day $(\mathrm{N}=4)$; the mean transit time fell significantly from $63.0( \pm 16 \cdot 7) \mathrm{h}$ to $38.8( \pm 7 \cdot 7) \mathrm{h}$ on this high-fibre diet. As judged by "Student's" $t$ test these differences were significant $(t=3.8, \mathrm{P}<0.02)$. Thus, the total number of bacteria excreted daily increased about three-fold when a high-fibre diet was eaten.

\section{The dominant bacteria}

Non-sporing anaerobic bacteria were the predominant faecal organisms isolated from all the subjects examined, but the dominant species was different for each of the four subjects. Indeed, the combination of species isolated from the faeces was characteristic of each individual. Bact. fragilis, Bifidobacterium 

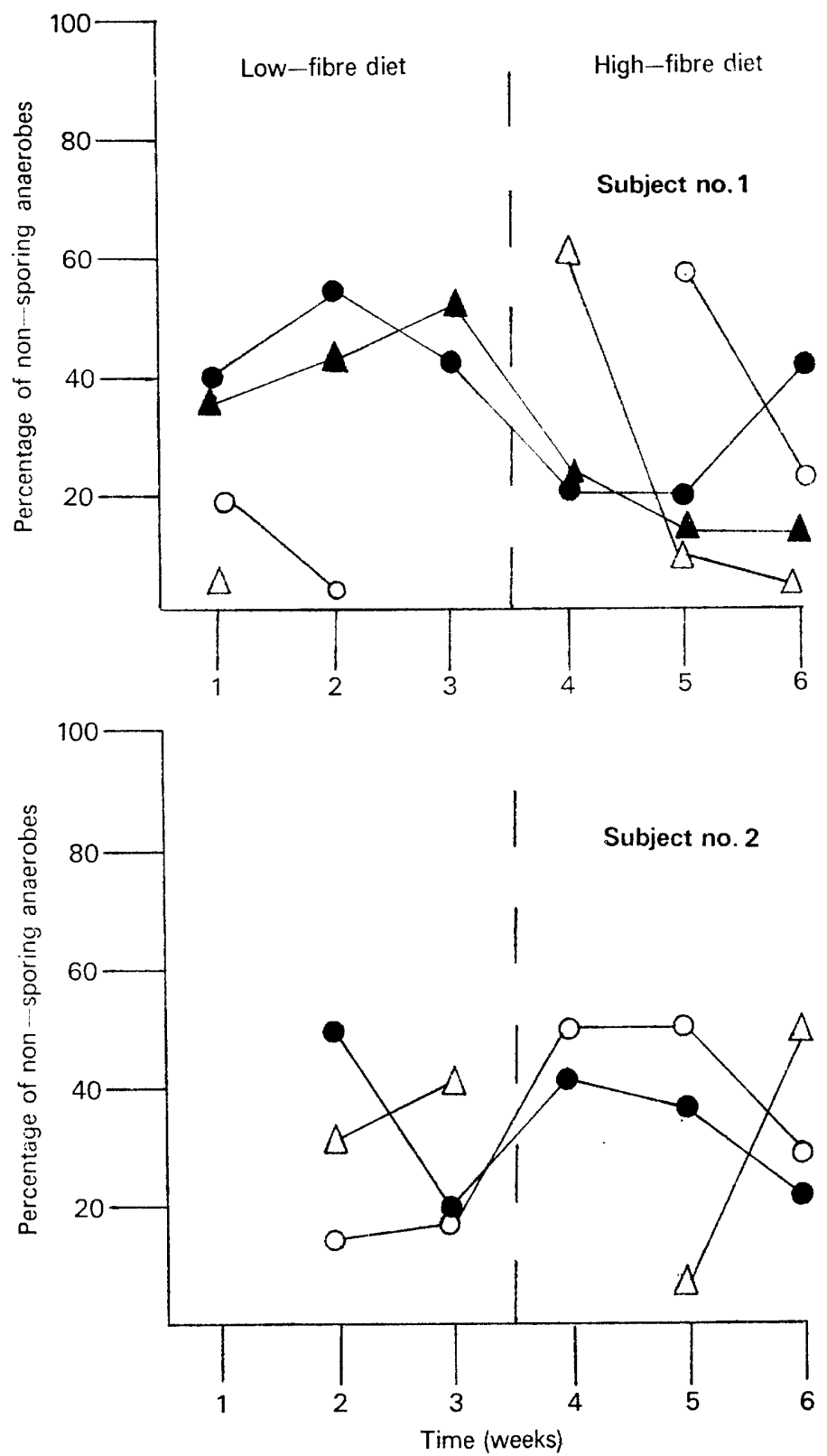

FIG. 1.-Variations in relative proportions (expressed as percentages of total anaerobes) of the stated species of non-sporing anaerobic bacteria isolated from the faeces of subjects nos. 1 and 2 during change from low-fibre to high-fibre diet: $-0=$ Bacteroides fragilis; $\mathrm{O}-\mathrm{O}=$ Bifidobacterium adolescentis; $-\Lambda=$ Peptococcus asaccharolyticus $; \triangle-\triangle=$ Eubacterium aerofaciens. 
adolescentis and Eubacterium aerofaciens were isolated from specimens obtained from subjects nos. 1 and 2 during both dietary periods. Specimens from subject no. 4 yielded a greater proportion of Bact. fragilis than did specimens from the other subjects. Peptococcus asaccharolyticus was isolated from subject no. 1 only. Isolates obtained from specimens produced by subject no. 3 were almost all identified as Bi. adolescentis. The changes in the patterns of these isolations with time are presented in fig. 1 (subjects 1 and 2) and fig. 2 (subjects 3 and 4).

In addition to these organisms, one strain of Fusobacterium prausnitzii was isolated from each of subjects nos. 3 and 4; two strains of Eu. rectale were isolated from subject no. 1, and two strains of Pept. productus were isolated from subject no. 2. In all, 309 strains of non-sporing anaerobic bacteria were isolated; of these, 27 isolates were not identified.

\section{Faecal $\beta$-glucuronidase}

The concentration of faecal $\beta$-glucuronidase was assayed in two subjects; it was unaffected by the change in diet.

\section{Clostridia able to dehydrogenate the steroid nucleus (NDC)}

Clostridia with this biochemical activity (Goddard et al., 1975) were isolated from only one of the four subjects studied. Their concentration was not influenced by changes in diet. Indeed, the number of clostridia detected in all subjects varied little (the table). It should be noted that, as a result of the design of the study, the presence of NDC clostridia could have been masked by the presence of other clostridia unless the NDC clostridia exceeded $10 \%$ of the total.

\section{Discussion}

Diet is thought to be one of the main factors controlling the intestinal flora (Dudgeon, 1926), but attempts to alter the flora of adult man by dietary changes have produced disappointing results. Only the feeding of low-residue liquid-formula diets has produced reproducible changes (Attebery, Sutter and Finegold, 1972; Crowther et al., 1973). However, alterations in the metabolic activity of the flora can be shown even when alterations in the bacterial genera and species making up the flora cannot always be detected by classical bacteriological procedures. Thus, the feeding of meat alters the levels of $\beta$-glucuronidase in faeces (Reddy, Weisburger and Wynder, 1974) although, at best, only minimal changes in the flora are detected (Maier et al., 1974).

Most components of the diet are absorbed very efficiently by the small intestine. Any influence of protein, fat and digestible carbohydrate will, therefore, be mediated by the host metabolism and may be a long-term process. On the other hand, it might be expected that any effect of substances, such as " fibre", that pass directly into the colon would be manifested quickly. The amount of fibre entering the large bowel is said to influence the flora and control the development of large-bowel cancer. 

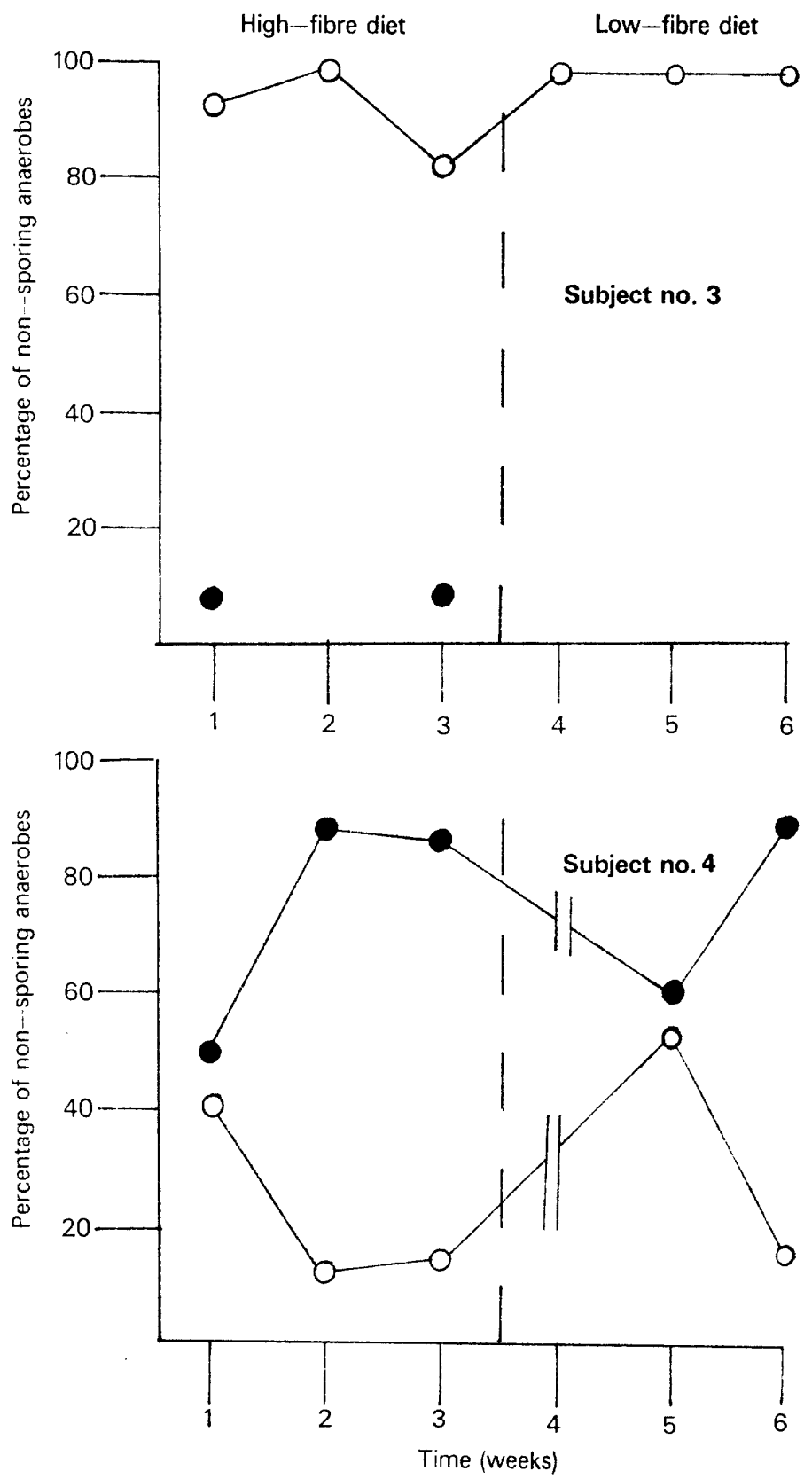

FIG. 2.-Variations in the relative proportions (expressed as percentages of total anaerobes) of the stated species of non-sporing anaerobic bacteria isolated from the faeces of subjects nos. 3 and 4 during change from high fibre to low fibre diet: $-\mathrm{O}=$ Bact. fragilis; $\mathrm{O}-\mathrm{O}=\mathrm{Bi}$. adolescentis. 
TABLE

$\log _{10}$ numbers of bacteria per $g$ wet weight of faeces from four subjects on low-and high-fibre diets

\begin{tabular}{|c|c|c|c|c|c|c|c|c|}
\hline \multirow{3}{*}{$\begin{array}{l}\text { Group of } \\
\text { bacteria } \\
\text { isolated }\end{array}$} & \multicolumn{8}{|c|}{ Mean (range) $\log _{10}$ number of organisms per $g$ of faeces (with the stated diet) from subject no. } \\
\hline & \multicolumn{2}{|c|}{1} & \multicolumn{2}{|c|}{2} & \multicolumn{2}{|c|}{3} & \multicolumn{2}{|c|}{4} \\
\hline & $\begin{array}{c}\text { Low } \\
\text { fibre } \\
\text { (2 samples) }\end{array}$ & $\begin{array}{c}\text { High } \\
\text { fibre } \\
\text { (4 samples) }\end{array}$ & $\begin{array}{c}\text { Low } \\
\text { fibre } \\
\text { (1 sample) }\end{array}$ & $\begin{array}{c}\text { High } \\
\text { fibre } \\
\text { (2 samples) }\end{array}$ & $\begin{array}{c}\text { Low } \\
\text { fibre } \\
\text { (1 sample) }\end{array}$ & $\begin{array}{c}\text { High } \\
\text { fibre } \\
\text { (3 samples) }\end{array}$ & $\begin{array}{c}\text { Low } \\
\text { fibre } \\
\text { (2 samples) }\end{array}$ & $\begin{array}{c}\text { High } \\
\text { fibre } \\
\text { (4 samples }\end{array}$ \\
\hline Enterobacteria & $\begin{array}{c}7 \cdot 2 \\
(7 \cdot 3-7 \cdot 1)\end{array}$ & $\begin{array}{c}7 \cdot 1 \\
(5 \cdot 9-7 \cdot 8)\end{array}$ & $\begin{array}{c}8.5 \\
\ldots\end{array}$ & $\begin{array}{c}7 \cdot 8 \\
(6 \cdot 6-9 \cdot 0)\end{array}$ & $\begin{array}{c}7.9 \\
\ldots\end{array}$ & $\begin{array}{c}7 \cdot 0 \\
(5 \cdot 0-7 \cdot 6)\end{array}$ & $\begin{array}{c}7 \cdot 4 \\
(6 \cdot 3-8 \cdot 5)\end{array}$ & $\begin{array}{c}7 \cdot 5 \\
(7 \cdot 1-8 \cdot 6)\end{array}$ \\
\hline Enterococci & $\begin{array}{c}7 \cdot 7 \\
(6 \cdot 3-9 \cdot 3)\end{array}$ & $\begin{array}{c}7 \cdot 2 \\
(6 \cdot 3-8 \cdot 9)\end{array}$ & $\begin{array}{c}7 \cdot 8 \\
\ldots\end{array}$ & $\begin{array}{c}7 \cdot 3 \\
(6 \cdot 6-8 \cdot 0)\end{array}$ & $\begin{array}{c}7 \cdot 3 \\
\ldots\end{array}$ & $\begin{array}{c}6 \cdot 1 \\
(5 \cdot 0-7 \cdot 6)\end{array}$ & $\begin{array}{c}6 \cdot 7 \\
(5 \cdot 9-7 \cdot 5)\end{array}$ & $\begin{array}{c}6 \cdot 7 \\
(5 \cdot 5-9 \cdot 1)\end{array}$ \\
\hline $\begin{array}{l}\text { "Viridans " } \\
\text { streptococci }\end{array}$ & $\begin{array}{c}7 \cdot 8 \\
(6 \cdot 3-9 \cdot 3)\end{array}$ & $\begin{array}{c}8 \cdot 1 \\
(7 \cdot 6-9 \cdot 3)\end{array}$ & $\begin{array}{l}7 \cdot 9 \\
\ldots\end{array}$ & $\begin{array}{c}8 \cdot 5 \\
(6 \cdot 6-10 \cdot 5)\end{array}$ & $\begin{array}{l}7 \cdot 6 \\
\ldots\end{array}$ & $\begin{array}{c}6 \cdot 5 \\
(5 \cdot 5-7 \cdot 6)\end{array}$ & $\begin{array}{c}6 \cdot 9 \\
(6 \cdot 3-7 \cdot 6)\end{array}$ & $\begin{array}{c}7 \cdot 4 \\
(6 \cdot 3-8 \cdot 6)\end{array}$ \\
\hline Lactobacilli & $\left(\begin{array}{c}3 \cdot 5 \\
(D-5 \cdot 0)\end{array}\right.$ & $\begin{array}{c}6 \cdot 3 \\
(5 \cdot 9-6 \cdot 6)\end{array}$ & $\begin{array}{c}4 \cdot 1 \\
\ldots\end{array}$ & $\begin{array}{c}5 \\
(4 \cdot 5-5 \cdot 0)\end{array}$ & $\begin{array}{c}4.8 \\
\ldots\end{array}$ & $\begin{array}{c}4 \cdot 4 \\
(4 \cdot 2-4 \cdot 8)\end{array}$ & $\begin{array}{c}3 \cdot 6 \\
(3 \cdot 0-4 \cdot 3)\end{array}$ & $\begin{array}{c}4 \cdot 9 \\
(4 \cdot 6-5 \cdot 6)\end{array}$ \\
\hline Clostridia & $\begin{array}{c}6.5 \\
(6 \cdot 5-6 \cdot 6)\end{array}$ & $\begin{array}{c}6 \cdot 0 \\
(5 \cdot 0-7 \cdot 1)\end{array}$ & $\begin{array}{l}6 \cdot 2 \\
\ldots\end{array}$ & $\begin{array}{c}5 \cdot 3 \\
(5 \cdot 3-5 \cdot 4)\end{array}$ & $\begin{array}{l}4 \cdot 0 \\
\ldots\end{array}$ & $\begin{array}{c}3 \cdot 6 \\
(3 \cdot 6-3 \cdot 7)\end{array}$ & $\begin{array}{c}6.8 \\
(6.7-6.9)\end{array}$ & $\begin{array}{c}6 \cdot 0 \\
(5 \cdot 0-6 \cdot 5)\end{array}$ \\
\hline Bacteroides & $\begin{array}{c}0.9 \\
(9 \cdot 7-10 \cdot 1)\end{array}$ & $\begin{array}{c}9 \cdot 9 \\
(\mathrm{~N}-10 \cdot 3)\end{array}$ & $\begin{array}{c}10 \cdot 3 \\
\ldots\end{array}$ & $\begin{array}{c}10 \cdot 25 \\
(10 \cdot 0-10 \cdot 5)\end{array}$ & $\begin{array}{l}\mathbf{N} \\
\cdots\end{array}$ & $(\mathrm{N}-10 \cdot 0)$ & $\begin{array}{c}10 \cdot 0 \\
(9 \cdot 7-10 \cdot 3)\end{array}$ & $\begin{array}{c}10 \cdot 4 \\
(9 \cdot 7-11 \cdot 0)\end{array}$ \\
\hline Bifidobacteria & $\begin{array}{c}9.5 \\
(\mathrm{~N}-10 \cdot 0)\end{array}$ & $\begin{array}{c}9 \cdot 8 \\
(\mathrm{~N}-10 \cdot 2)\end{array}$ & $\begin{array}{c}10 \cdot 0 \\
\ldots\end{array}$ & $\begin{array}{c}10 \cdot 4 \\
(10 \cdot 3-10 \cdot 6)\end{array}$ & $\begin{array}{c}10 \cdot 2 \\
\ldots\end{array}$ & $\begin{array}{c}10 \cdot 2 \\
(9 \cdot 5-10 \cdot 9)\end{array}$ & $\begin{array}{c}9 \cdot 1 \\
(\mathrm{~N}-9 \cdot 3)\end{array}$ & $\begin{array}{c}9 \cdot 3 \\
(\mathrm{~N}-9 \cdot 7)\end{array}$ \\
\hline Eubacteria & $\begin{array}{c}9 \cdot 0 \\
(\mathrm{~N}-9 \cdot 1)\end{array}$ & $\begin{array}{c}9.4 \\
(N-10 \cdot 0)\end{array}$ & $\begin{array}{c}10 \cdot 1 \\
\ldots\end{array}$ & $\begin{array}{c}9 \cdot 5 \\
(N-10 \cdot 6)\end{array}$ & $\begin{array}{l}\mathbf{N} \\
\cdots\end{array}$ & $\begin{array}{l}\mathrm{N} \\
\ldots\end{array}$ & $\begin{array}{l}\mathbf{N} \\
\cdots\end{array}$ & $\begin{array}{l}\mathrm{N} \\
\cdots\end{array}$ \\
\hline Peptococci & $\begin{array}{c}10 \cdot 0 \\
(9 \cdot 0-11 \cdot 1)\end{array}$ & $\begin{array}{c}9 \cdot 4 \\
(\mathrm{~N}-10 \cdot 0)\end{array}$ & $\begin{array}{l}\mathbf{N} \\
\cdots\end{array}$ & $\begin{array}{l}\mathbf{N} \\
\cdots\end{array}$ & $\begin{array}{l}\mathbf{N} \\
\cdots\end{array}$ & $\begin{array}{l}\mathbf{N} \\
\cdots\end{array}$ & $\begin{array}{l}\mathrm{N} \\
\cdots\end{array}$ & $\begin{array}{l}N \\
\cdots\end{array}$ \\
\hline
\end{tabular}

$\mathrm{D}=$ less than $2 \cdot 0 ; \mathrm{N}=$ less than $9 \cdot 0$.

Means were not calculated if the organism in question was not isolated from more than one sample.

Cancer of the colon and rectum occurs primarily in developed countries. The incidence is high in Western Europe and North America but low in Africa, Asia and most of South America and this is thought to be related to the bacterial production or activation of carcinogens in the intestine. In a previous study, in which the flora of faeces from populations in areas with low and high incidences of colon cancer, bacteroides organisms were shown to be more common in faeces from areas in which the incidence of cancer of the large bowel is high whereas eubacteria were more common in faeces from lowincidence regions (Peach et al., 1974). Bile salts are thought to provide the substrate for the production of carcinogens or co-carcinogens by bacteria. International comparisons have shown that the concentration of bile acids in faeces is higher in high-incidence areas than in low-incidence areas; moreover, the bile acids from high-incidence populations were subject to a greater degree of bacterial degradation (Hill et al., 1971). A pathway for the production of carcinogens from bile acids was postulated by Hill (1971), a key reaction in this scheme being the dehydrogenation of the steroid nucleus. This reaction is performed only by clostridia, notably Clostridium paraputrificum. These organisms are isolated more frequently from populations in high-incidence areas than from populations in areas of low incidence (Drasar et al., 1976). In addition, evidence of the probable significance of these clostridia has been provided by a retrospective study of cancer patients (Hill et al., 1975).

Burkitt (1971) suggested that the differences in the incidence of cancer 
of the large bowel resulted from the influence of the large amounts of dietary fibre consumed in low-incidence areas on the bacterial flora and physiology of the large bowel. The addition of bran to the diet of persons in high-incidence areas was suggested as a prophylactic measure. The relationship of fibre intake to the incidence of large-bowel cancer has been studied in several epidemiological investigations; no strong correlation can be demonstrated between a low incidence of large bowel cancer and fibre consumption (Irving and Drasar, 1973; Armstrong and Doll, 1975). This lack of correlation may be explained by the differences in the types of fibre consumed in various parts of the world; wheat bran is not consumed by people living in low-incidence areas.

In the present study, no effect of bran on the numbers and types of bacteria present in faeces could be demonstrated although an increase in the rate of intestinal transit was observed. As mentioned previously, when the flora of faeces from populations in low- and high-incidence areas was examined, differences were found in the proportion of the various groups of non-sporing anaerobic bacteria isolated (Peach et al., 1974). If these results are to be explained in terms of the intake of fibre it would be expected that a decrease in the numbers of bacteroides organisms and an increase in the numbers of eubacteria would be seen. Moreover, NDC clostridia would be expected to disappear under the influence of wheat fibre. No such effect was demonstrated. Although NDC clostridia can be reliably detected only when not masked by other organisms, a reduction in their number to less than $10 \%$ of the total would have been detected. Work on these organisms is hampered by the lack of a reliable selective system. No change in the level of $\beta$-glucuronidase in faeces was detected in the two subjects from whom samples were assayed.

The most notable observation made during the present study was that the dominant non-sporing anaerobic bacterial species found in the intestine seemed to be a characteristic of the subject examined. Previous studies have suggested this (see, for example, Moore and Holdeman, 1974); whilst Moore and Holdeman's study relates to the exhaustive study of single samples, our conclusion resulted from the examination of several samples from each subject. The singularity of the flora is well illustrated by our findings with subject no. 3 whose flora was dominated by $B i$. adolescentis; even when this subject was consuming a high-fibre diet, $B i$. adolescentis was never less than $80 \%$ of the non-sporing anaerobic bacteria isolated. Although some fluctuation in the relative proportions of the various non-sporing anaerobic bacteria was observed during this study, these changes could not be ascribed to the dietary changes; the differences between subjects were greater than those within subjects throughout the investigation.

When considering the factors that control the flora, the genetic constitution of the host should perhaps be considered. During studies of the inherited disease familial polyposis coli, it was shown that in patients with this condition the metabolism of cholesterol by the large bowel flora did not take place although the flora could perform this reaction in vitro (Bone, Drasar and Hill, 1975). It seems that the resistance of the flora to change despite major alterations of diet reflects the over-riding controlling role of host factors that are 
yet to be defined. Our study indicates that a brief change of diet seems to have little effect on the remarkable homeostasis of the bowel.

\section{SUMMARY}

The effect on the faecal flora of adding wheat fibre to a controlled diet in four healthy volunteers for a 3-week period has been observed. No change in the concentration of the bacteria in the bacterial groups counted was found, although there was a slight increase in total output associated with increased faecal weight. The predominant organisms in all subjects were non-sporing anaerobes, but the dominant species in each subject was different and was unaffected by changing the diet. Similarly, the concentration of faecal $\beta$-glucuronidase detected in two subjects was unaltered and the concentration of clostridia able to dehydrogenate the steroid nucleus found in one subject was unaltered.

It is suggested that the faecal microflora is not primarily controlled by the presence of undigested food residues in the large bowel.

B. S. D. thanks the Cancer Research Campaign and J. H. C. thanks the British Nutrition Foundation for financial support.

\section{REFERENCES}

ARANKI, A., Syed, S. A., KenNeY, E. B. AND Freter, R. 1969. Isolation of anaerobic bacteria from human gingiva and mouse cecum by means of a simplified glove box procedure. Appl. Microbiol., 17, 568.

ARMSTRONG, B. AND Doll, R. 1975. Environmental factors and cancer incidence and mortality in different countries with special reference to dietary practices. Int. J. Cancer, 15, 617.

Attebery, H. R., Sutter, V. L. AND Finegold, S. M. 1972. Effect of partially chemically defined diet on normal human fecal flora. Am. J. Clin. Nutr., 25, 1391.

Bone, E., Drasar, B. S. AND HiLl, M. J. 1975. Gut bacteria and their metabolic activities in familial polyposis. Lancet, $1,111$.

BurkitT, D. P. 1971. Epidemiology of cancer of the colon and rectum. Cancer, Philad., $28,3$.

CowgILL, G. R. AND ANDERson, W. E. 1932. Laxative effects of wheat bran and washed bran in healthy men. A comparative study. J. Am. med. Ass., 98, 1866.

CrowTHER, J. S. 1971. Transport and storage of faeces for bacteriological examination. J. appl. Bact., 34, 477.

Crowther, J. S., Drasar, B. S., Goddard, P., Hill, M. J. and Johnson, K. 1973. The effect of a chemically defined diet on the faecal flora and faecal steroid concentration. Gut, $14,790$.

Drasar, B. S. 1967. Cultivation of anaerobic intestinal bacteria. J. Path. Bact., 94, 417.

DrASAR, B. S. 1974. The isolation and identification of non-sporing anaerobes. In Infection with non-sporing anaerobic bacteria, edited by I. Phillips and M. Sussman, Edinburgh, London and New York, p. 20.

Drasar, B. S., Goddard, P., Heaton, S., Peach, S. and West, B. 1976. Clostridia isolated from faeces. J. med. Microbiol., 9, 63.

DuDGEON, L. S. 1926. A study of the intestinal flora under normal and abnormal conditions. J. Hyg., Camb., 25, 119.

Goddard, P., Fernandez, F., West, B., Hill, M. J. and Barnes, P. 1975. The nuclear dehydrogenation of steroids by intestinal bacteria. J. med. Microbiol., 8, 429.

Harvey, R. F., Pomare, E. W. and Heaton, K. W. 1973. Effects of increased dietary fibre on intestinal transit. Lancet, 1, 1278. 
HiLl, M. J. 1971. Gut bacteria steroids and cancer of the large bowel. In Some implications of steroid hormones in cancer, edited by D. C. Williams and M. H. Briggs, London, p. 94.

Hill, M. J., Crowther, J. S., Drasar, B. S., Hawksworth, G., Aries, V. and Williams, R. E. O. 1971. Bacteria and aetiology of cancer of large bowel. Lancet, 1, 95.

Hill, M. J., Drasar, B. S., Williams, R. E. O., Meade, T. W., Cox, A. G., Simpson, J. E. P. AND Morson, B. 1975. Faecal bile acids and clostridia in patients with cancer of the large bowel. Lancet, 1, 535.

Irving, D. AND DraSar, B. S. 1973. Fibre and cancer of the colon. Br. J. Cancer, 28, 462.

Jenkins, D. J. A., Hill, M. S. AND Cummings, J. H. 1975. Effect of wheat fibre on blood lipids, fecal steroid excretion and serum iron. Am. J. clin. Nutr., 28, 1408.

Maier, B. R., Flynn, M. A., Burton, G. C., Isutakawa, R. K. and Hentges, D. J. 1974. Effects of a high beef diet on bowel flora. Am. J. clin. Nutr., 27, 1470.

Moore, W. E. C. and Holdeman, L. V. 1974. Human fecal flora. The normal flora of 20 Japanese Hawaiians. Appl. Microbiol., 27, 961.

Peach, S., Fernandez, F., Johnson, K. and Drasar, B. S. 1974. The non-sporing anaerobic bacteria in human faeces. J. med. Microbiol., 7, 213.

ReDDY, B. S., WeISBURGer, J. H. AND WYNDER, E. I. 1974. Fecal bacterial $\beta$-glucuronidase. Control by diet. Science, N.Y., 183, 416.

REDDY, B. S. AND WYNDER, E. L. 1973. Large bowel carcinogenesis: Faecal constituents of populations with diverse incidence rates of colon cancer. J. Natn. Cancer Inst., 50, 1437.

Southgate, D. A. T. 1969. Determination of carbohydrate in food. II. Unavailable carbohydrate. J. Sci. Fd. Agric., $20,331$. 